\title{
A Short Review of Fuel Consumption Rates of Whole Tree and Cut-To-Length Timber Harvesting Methods
}

\author{
Mohammad Reza Ghaffariyan ${ }^{1 *}$, Robin Apolit $^{2}$ and Martin Kuehmaier ${ }^{3}$ \\ ${ }^{1}$ AFORA, University of the Sunshine Coast, Australia \\ ${ }^{2}$ Universite de Lorraine ENSTIB, France \\ ${ }^{3}$ University of Natural Resources and Life Sciences, Vienna, Austria
}

Received: 䟧 October 30, 2018; Published: 眥 November 08, 2018

*Corresponding author: Mohammad Reza Ghaffariyan, AFORA, University of the Sunshine Coast, Australia

\begin{abstract}
The fuel consumption of equipment during forest harvesting operations is still not well known and existing measurement technologies are largely untested. Considering forest industry's need, some countries have developed and compared tools to quantify, control and analyses fuel consumption to create suitable analysis methods. Comprehensive trials have been carried out by researchers in different countries to quantify the fuel consumption rates for different harvesting methods. This article provides a short review of fuel consumption rates of whole tree and cut-to-length harvesting methods. The article explains the factors influencing the fuel consumption and provides suggestions to control and reduce fuel consumption of harvesting machines.
\end{abstract}

Keywords: Fuel Consumption Rate; Forest Harvesting; Whole Tree; Cut-to-length

\section{Introduction}

The fuel consumption of equipment during forest harvesting operations is still not well known and existing measurement technologies are largely untested. Considering forest industry's need, some countries have developed and compared tools to quantify, control and analyse fuel consumption to create suitable analysis methods. Despite environmental and economic concerns on the fuel consumption of various harvesting machines due to emissions and increasing fuel costs, there are not many studies available on this topic. This short review article aimed to collect the relevant information through reviewing previous studies in different countries.

\section{Fuel Consumption Rates}

Comprehensive trials have been carried out to quantify the fuel consumption rates for different harvesting methods [1]. The cut-to-length (CTL) method, with a harvester and forwarder, used $2.0 \mathrm{~L} / \mathrm{m}^{3}$ which is lower than $2.7 \mathrm{~L} / \mathrm{m}^{3}$ for the whole tree (WT) method, including a feller-buncher, skidder and processor. The CTL systems studied in Austria and Western Australia also had lower fuel consumption per unit volume harvested (Table 1). This might be a result of using two machines within the CTL method compared with three machines in the WT method. The WT operations in the Austrian study, using cable yarder, consumed less fuel per cubic meter of wood harvested than the Canadian and Western Australian case studies. These differences are most likely due to the Austrian case study having a chain saw for felling and a tower yarder for extraction that had very high productivity (Table 1). WT methods using skidders will be more common in areas with difficult terrain with steeper slopes and smaller tree sizes resulting in reduce machine productivity and typically increased fuel consumption per unit volume harvested. Transportation is the most fuel consuming element of a wood supply chain. In Sweden, secondary timber transport consumed about $50 \%$ of total fuel usage while harvesting and extraction operations consumed 33-40\% [2,3] analyzed the time and fuel consumption of round wood transportation in Austria using a monitoring system that combined information from the machine's computers (over CAN-bus) with GPS-data. An average $0.77 \mathrm{~L}$ of diesel fuel per $\mathrm{km}$ or $2.09 \mathrm{~L} / \mathrm{m}^{3}$ of wood was consumed during their study. This average consumption is higher than the results provided by Lindholm [2] of $0.56 \mathrm{~L} / \mathrm{km}$, but this is expected with longer transport distances on flatter terrain in Sweden. A survey of timber transport fuel consumption in south-east Victoria indicated a result between the Swedish and Austrian results with a 
fuel rate of $0.62 \mathrm{~L} / \mathrm{km}$ for single truck and $0.67 \mathrm{~L} / \mathrm{km}$ for B-double truck [4].

Table 1: Fuel consumption for two harvesting methods.

\begin{tabular}{|c|c|c|c|}
\hline \multirow{2}{*}{$\begin{array}{c}\text { Harvesting } \\
\text { Method }\end{array}$} & $\begin{array}{c}\text { Canadian } \\
\text { case } \\
\text { study }\end{array}$ & Austrian case study & $\begin{array}{c}\text { Australian } \\
\text { case study } \\
\text { in Blue gum } \\
\text { plantations }\end{array}$ \\
\cline { 2 - 4 } & 2.7 & $\begin{array}{c}2.2 \\
\text { (chain saw, yarding } \\
\text { with tower yarder, } \\
\text { processor) }\end{array}$ & 2.6 \\
\hline $\begin{array}{c}\text { WT (feller- } \\
\text { buncher, } \\
\text { skidder, } \\
\text { processor) }\end{array}$ & 2.0 & 1.6 & 1.4 \\
\hline $\begin{array}{c}\text { CTL (harvester- } \\
\text { forwarder) }\end{array}$ & & \multicolumn{2}{|c|}{ Total Fuel Consumption (L/ ${ }^{3}$ ) } \\
\hline
\end{tabular}

\section{Controlling and Reducing Fuel Consumption Rates}

Different approaches can be applied to control and reduce fuel consumption in forest operations. FP Innovations in Canada have produced a guide that has also been adapted by Tigercat $[5,6]$. A few of the key suggestions from guide that may apply for any forest operation include:

A. Use diesel engines at their maximum torque to utilize all potential.

B. Thermostatic fans and hydraulically driven variablespeed fans should not operate at full speed under all working conditions. A fan that operates continuously at full speed consumes 1 to 2 liters of fuel per hour.

C. Use the work lights only when required, their use can increase fuel use by $0.5 \mathrm{~L} / \mathrm{h}$.

D. Minimize idling. A typical feller-buncher engine can consume up to $2.5 \mathrm{~L} / \mathrm{h}$ while idling.

E. Keep the radiator and oil cooler clean. This helps keep the oil at the right temperature to reduce fan operation for thermostat-controlled fans.

F. Choose tyres to minimize sinking and loss of traction. Skidders equipped with high-floatation tyres have lower fuel consumption than skidders with narrow tires on soils prone to rutting.

G. Plan landing and skid trails in the most appropriate locations. Where possible plan landing location downhill as downhill skidding and forwarding require less fuel.

Other ideas have been suggested by Finnish scientists to reduce fuel consumption and emissions of ground-based logging systems [7]. These ideas are equally applicable in Australian forest operations;
H. Improve driver education, to educate drivers about driving techniques to reduce fuel consumption and to improve driver safety.

I. Switch to another transportation mode, e.g., rail if it is a viable service.

J. Use the most appropriate size of equipment for the task.

K. Integrate operations (e.g. integrating biomass/residue collection with industrial wood recovery by forwarders in pine plantations in New South Wales and south west Western Australia $[8,9]$.

L. Use alternate fuels e.g., biofuels derived from forest biomass.

\section{Parameters Influencing Fuel Consumption Rates}

The influencing parameters are mainly machine design (60\%), engine technology (20\%) and operator's work method (20\%) [5]. In a German case study, harvesters, forwarders and skidders were classified into small, medium and large classes based on their engine power. Fuel consumption was found to be lower for smaller engine powers which can be taken into consideration as one of the criteria to choose optimum machine size/type [10]. Increased truck payloads have also been shown to reduce fuel consumption per $\mathrm{m}^{3}$ of wood delivered by over $20 \%[11,12]$.

\section{Conclusion}

Fuel consumption is impacted by machine design thus choosing appropriate machine size for each task is a key decision. Skilled and educated operators can play a key role to reduce machine fuel usage. A few studies have been recently conducted but more comprehensive trials will be required in harvesting operations to effectively explore how to better manage and reduce fuel consumption within the forestry supply chain.

\section{References}

1. Sambo SM (2002) Fuel consumption for ground-based harvesting systems in western Canada. FERIC Advantage report 3(29): 12.

2. Lindholm EL (2006) Energy use in Swedish forestry and its environmental impact. Licentiate thesis, p. 28.

3. Holzleitner F, Kanzian C, Stampfer K (2011) Analyzing time and fuel consumption in road transport of round wood with an onboard fleet manager. European Journal Forest Research 130(2): 293-301.

4. Griffin R, Brown M (2010) Forest truck fuel consumption survey. CRC for Forestry Bulletin.

5. Makkonen I (2004) Saving fuel in mechanized forestry operations. Forest Engineering Research Institute of Canada, Pointe-Claire, QC, p. 10.

6. http://www.tigercat.com/service-tips/fuel-economy-counts/

7. Karjalainen T, Asikainen A (1996) Greenhouse gas emissions from the use of primary energy in forest operations and long-distance transportation of timber in Finland. Institute of Chartered Foresters Forestry 69(3): 215-228. 
8. Walsh D, Wiedemann J, Strandgard M, Ghaffariyan MR, Skinnell J (2011) FibrePlus study: Harvesting stemwood waste pieces in pine clearfall. CRC for Forestry, Bulletin 18: 3.

9. Ghaffariyan MR, Spinelli R, Magagnotti N, Brown M (2015) Integrated harvesting for conventional log and energy wood assortments: a case study in a pine plantation in Western Australia. Southern Forests: a Journal of Forest Science 77(4): 249-254.
10. Wesie G, Rosenbach D (2011) Kraftstofverbrauch von Forstmaschinen senken 1(2): 7-11.

11. Löfroth C, Svenson G (2012) ETT- Modular system for timber transport - One More Stack (ETT) and Bigger Stacks (ST).

12. Ghaffariyan MR, Brown M (2013) Selecting the efficient harvesting method using multiple criteria analysis: A case study in south-west Western Australia. Journal of Forest Science (Czech) 59(12): 479-486.

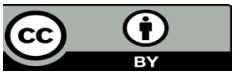

This work is licensed under Creative Commons Attribution 4.0 License

To Submit Your Article Click Here:

Submit Article

DOI: $10.32474 /$ CIACR.2018.05.000209

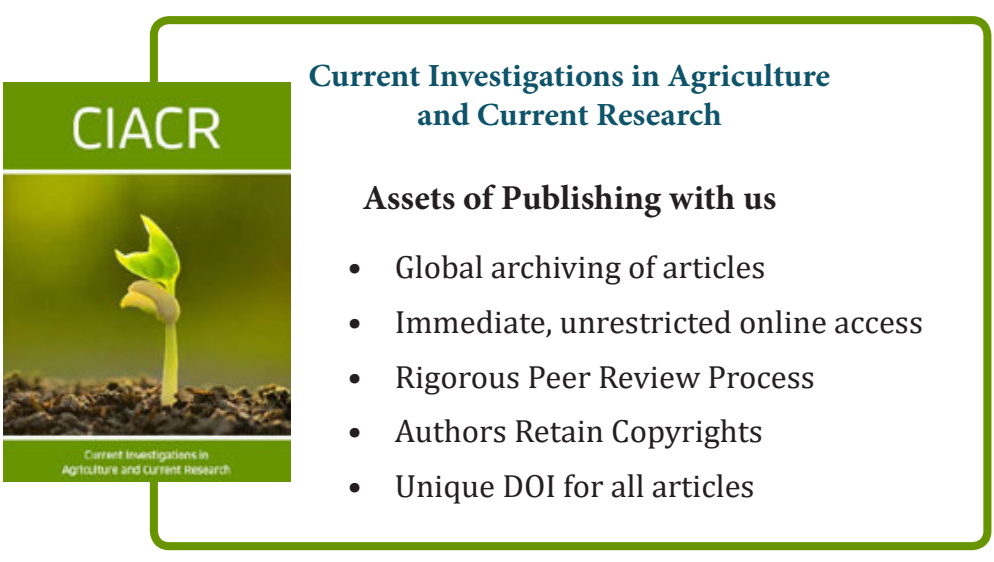

